\title{
The case for a Neoproterozoic Oxygenation Event: Geochemical evidence and biological consequences
}

\author{
Graham Shields-Zhou, Dept. of Earth Sciences, University \\ College London, Gower Street, London WC1E 6BT, UK, and LPS, \\ Nanjing Institute of Geology and Palaeontology (NIGPAS), \\ Chinese Academy of Sciences, 39 East Beijing Road, Nanjing \\ 210008, China; Lawrence Och, Dept. of Earth Sciences, Univer- \\ sity College London, Gower Street, London WC1E 6BT, UK
}

\begin{abstract}
The Neoproterozoic era marked a turning point in the development of the modern earth system. The irreversible environmental changes of that time were rooted in tectonic upheavals that drove chain reactions between the oceans, atmosphere, climate, and life. Key biological innovations took place amid carbon cycle instability that pushed climate to unprecedented extremes and resulted in the ventilation of the deep ocean. Despite a dearth of supporting evidence, it is commonly presumed that a rise in oxygen triggered the evolution of animals. Although geochemical evidence for oxygenation is now convincing, our understanding of the Neoproterozoic earth system and of early animal evolution has changed apace, revealing an altogether more complicated picture in which the spread of anoxia played an important role. The challenge to future researchers lies in unraveling the complex entanglement of earth system changes during this pivotal episode in Earth's history.
\end{abstract}

\section{INTRODUCTION}

Today, atmospheric oxygen plays a crucial role in shaping the surface of our planet. However, during most of Earth's history, molecular oxygen was only sparsely available and probably accumulated in two broad steps: during the Great Oxygenation (or Oxidation) Event (GOE) at $2.4 \mathrm{Ga}$ (e.g., Holland, 2002) and then during the Neoproterozoic Oxygenation Event (or NOE) almost two billion years later. Both events were accompanied by tectonic upheaval, climatic extremes, and biological innovations, implying a close interaction between the biotic and abiotic realms of system Earth.

The most commonly proposed environmental trigger for early animal evolution is oxygen (Nursall, 1959; Canfield and Teske, 1996). Most animals require molecular oxygen in order to produce their energy, and this has led to the widespread presumption that a rise in atmospheric oxygen was the essential precursor to the evolution of animals (Runnegar, 1991; Catling et al., 2005). Geochemical evidence for an oxygenation event during the late Precambrian has accumulated over the past quarter century, but it is still hard to distinguish atmospheric from ocean and global from local (or even porewater) redox changes. Evidence has emerged recently that the Neoproterozoic oceans were characterized by the spread of sulphidic and ferruginous anoxic environments, which is apparently at odds with the emergence of modern animal groups for which free sulphide is lethal and anoxia unfavorable.

Here we focus attention on the NOE, exploring geochemical evidence for its existence and examining the case for a causal relationship between oxygen and early animal evolution. Considering recent evidence for widespread ocean anoxia during the NOE, we speculate that metabolic versatility during the nascent stages of animal evolution may have been a key factor in the emergence and diversification of metazoan life on our planet, while later oxygenation allowed metazoans to increase their size and mobility.

Figure 1. (A) Proposed reconstruction of atmospheric $\mathrm{O}_{2}$ content through time expressed as percentage of present atmospheric level (PAL) of oxygen (after Canfield, 2005, with Phanerozoic estimates from Berner et al., 2003). Note that the uncertainty is quite high. Background displays redox conditions in the water column whereby the deep ocean was probably anoxic until the Great Oxygenation Event (GOE) in the early Paleoproterozoic, sulfidic during most of the Proterozoic, and primarily oxic after the Neoproterozoic Oxygenation Event (NOE). (B) The NOE possibly unleashed major biological innovations, including the appearance of new biological and ecological strategies: the first metazoans (Hoffman et al., 1990; Love et al., 2009); the appearance of first large and architecturally complex organisms during the Ediacaran (Narbonne, 2005); and the Cambrian Explosion (Marshall, 2006). A pronounced increase of maximum body size by several orders of magnitude occurred between 600 and 450 Ma. Red dots_-prokaryotes; orange diamonds - protists; brown square-vendobiont (probable multicellular eukaryote, e.g., Dickinsonia); blue squares-animals; green line-vascular plants (Payne et al., 2009). (C) $\delta^{13} \mathrm{C}$ record throughout Earth's history (compiled by Campbell and Allen, 2008). (D) Normalized seawater ${ }^{87} \mathrm{Sr} /{ }^{86} \mathrm{Sr}$ curve (from Shields, 2007). (E) Compilation of sulfur isotope data measured in sulphide- and sulphate-bearing minerals. $\Delta^{34} \mathrm{~S}$ values in the Archean do not exceed 20\% and maximal Paleo- and Mesoproterozoic $\Delta^{34} \mathrm{~S}$ values are around $45 \%$. It is only from the Neoproterozoic on that sulphur fractionation attains values between 40 and $70 \%$. Upper red curve illustrates maximal $\delta^{34} S_{\text {sufate }}$ values and is offset by $-55 \%$ (lower line) (most values were compiled by Canfield and Farquhar, 2009). (F) Compilation of molybdenum concentrations in black shales from different sections around the world (mainly from Scott et al., 2008, and references therein). (G) Compilation of vanadium concentrations in black shales. Precambrian data are rather sparse but still indicate a significant step toward much higher enrichment of $\mathrm{V}$ in black shales during the Precambrian-Cambrian transition (Precambrian data mainly from C. Scott, 2010, pers. comm.). (H) Key aspects of the Precambrian history of hexavalent chromium in sea water. Increasing $\mathrm{Cr}$ isotope fractionation $\left(\delta^{53} \mathrm{Cr}\right)$ recorded in banded iron formations (BIFs) between 2.8 and $2.45 \mathrm{Ga}$ indicate rise in oxidative weathering with a possible return to reduced atmospheric oxygen levels between 2.45 and 1.9 Ga. BIFs deposited during the late Neoproterozoic between ca. $750 \mathrm{Ma}$ and the Precambrian-Cambrian boundary record strongly positive $\delta^{53} \mathrm{Cr}$ values ranging from $0.9 \%$ to $4.9 \%$, which may provide further evidence for the NOE (from Frei et al., 2009).

GSA Today, v. 21, no. 3, doi: 10.1130/GSATG102A.1

E-mails: g.shields@ucl.ac.uk; l.och@ucl.ac.uk 


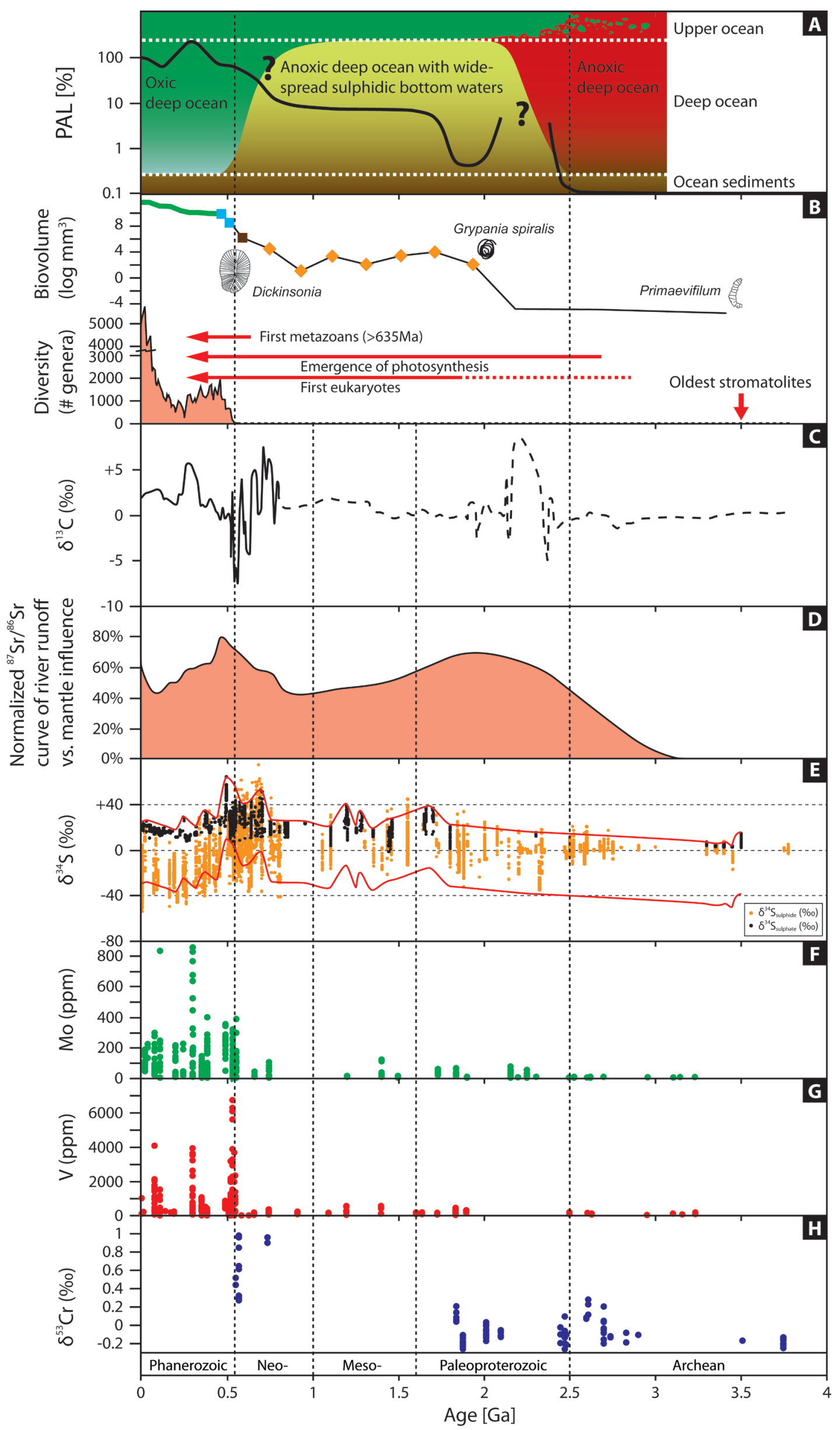




\section{GEOLOGICAL SETTING OF EARLY ANIMAL EVOLUTION}

By the beginning of the Neoproterozoic era, most of the continental crust had amalgamated into one vast supercontinent, Rodinia, which began to split apart after ca. 800 Ma (Evans, 2009). By ca. $700 \mathrm{Ma}$, our planet was dotted with microcontinents, predominantly at lower latitudes (Hoffman and Li, 2009). These crustal fragments accreted a series of volcanic arcs after ca. $650 \mathrm{Ma}$ and underwent serial collision, culminating in the formation of a new supercontinent, Gondwana, by ca. $520 \mathrm{Ma}$ (Campbell and Squire, 2010). The rifting of Rodinia formed the tectonic backdrop to decreasing levels of atmospheric $\mathrm{pCO}_{2}$ (Riding, 2006), which plunged the planet toward glaciation that reached low latitudes by $716 \mathrm{Ma}$ (Macdonald et al., 2010). How long this global cooling endured is still unknown, but isotopic evidence points to two or more intervals of extreme cold: from ca. $716 \mathrm{Ma}$ to ca. $670 \mathrm{Ma}$ (referred to but not proven to be equivalent to the "Sturtian" glaciations in Australia) and from ca. $650 \mathrm{Ma}$ to $635 \mathrm{Ma}$ (ascribed to the Elatina or "Marinoan" glaciation in Australia). Earlier Neoproterozoic glaciations ca. $750 \mathrm{Ma}$, and later ones (e.g., the ca. $580 \mathrm{Ma}$ Gaskiers glaciation), have enjoyed less attention and are unlikely to have been of global reach (Fairchild and Kennedy, 2007). The extraordinary circumstance of low altitude, equatorial ice cover (Hoffman and Li, 2009) at least twice during the Neoproterozoic led in part to the controversial "Snowball Earth Hypothesis" (Kirschvink, 1992; Hoffman et al., 1998), which has dominated debate on the Neoproterozoic earth system over the past decade.

Rodinia was possibly Earth's first green supercontinent because the oceans that surrounded it witnessed a remarkable diversification of eukaryotic life forms (Figs. 1 and 2). The first green algae (and possibly lichen) emerged around this time (Porter, 2004; Knoll et al., 2006) and would have revolutionized weathering and the global carbon cycle once they made it to land (Heckman et al., 2001; Lenton and Watson, 2004). Acritarch diversity (and presumably the diversity of eukaryotic plankton in general) crashed after Rodinia began to break up during the run-in to the Cryogenian glaciations (Nagy et al., 2009), but some new heterotrophic forms appeared as well. For example, the first appearance of biomineralizing eukaryotes in the form of fossil testate amoebae heralded the onset of glaciation around the world (Nagy et al., 2009).

The glacial interval between ca. $720 \mathrm{Ma}$ and $635 \mathrm{Ma}$ is thought to be the time during which the first animal lineages diverged from their single-celled ancestors (Peterson et al., 2008), presumably in intimate proximity with the icy, anoxic, and ferruginous environments of the glacial ocean (Canfield et al., 2008). Despite such challenging conditions, all modern eukaryote lineages survived Snowball Earth; i.e., the opisthokonts (e.g., fungi), the Amoebozoa (lobose amoebae), the plants (green and red algae), the chromalveolates (ciliates and dinoflagellates), and the Rhizaria (filose testae amoebae) (Porter, 2004). Although nothing resembling the common ancestor to all animals has been found in the rock record, fossil evidence for metazoan existence begins directly after the deglaciation that marks the beginning of the Ediacaran period at $635 \mathrm{Ma}$ (Yin et al., 2007; Cohen et al., 2009). Putative metazoans, in the form of benthic "fronds," first attained macroscopic size following the mid-Ediacaran "Gaskiers" glaciation of ca. $580 \mathrm{Ma}$
(Narbonne, 2005). The apparent association between climate change and fossil appearances, size change, and lifestyle has led naturally to the speculation that environmental factors directed biological evolution during the Neoproterozoic (e.g., Payne et al., 2009) (Figs. 1 and 2).

\section{THE EMERGENCE OF THE METAZOANS}

The abrupt appearance in the rock record of macroscopic life forms has perplexed geologists. By the middle of the nineteenth century, natural historians would speculate either that the fossil record was woefully incomplete (Darwin, 1859) or, following Abraham Gottlob Werner, that conditions had been hostile to complex life before the Cambrian (e.g., Daly, 1907). "Permissive evolution" through environmental change has continued to dominate notions of the Cambrian explosion, with the most commonly proposed trigger being oxygenation (Berkner and Marshall, 1965). Large organisms cannot exist beneath a minimum threshold of free oxygen (Catling et al., 2005). They need it to sustain their energy requirements and for structural support. Although primitive extant animals, such as the sponges (as well as their protist sister group, the choanoflagellates), are usually obligate aerobes, many animals can thrive in oxygen-poor environments, leading some to question the presumption that the very earliest animals were as dependent on oxygen as their modern counterparts (Budd, 2008). The existence of large, mobile animals since the beginning of the Phanerozoic certainly means that oxygen levels have not fallen beneath a minimum threshold since that time, but this fact cannot tell us when atmospheric oxygen first rose to such heights.

The biological case for a rise in oxygen during the Precambrian was first made in the 1920s with Oparin and Haldane independently realizing that life must have evolved under reducing conditions (Haldane, 1929; Oparin, 1938). Nursall (1959) postulated that Earth emerged from its anoxic state toward the end of the Precambrian and that this oxygenation event was the key environmental trigger for the Cambrian explosion. Geological evidence for the GOE almost two billion years earlier (Melezhik et al., 2005) led to the two-stage oxygenation paradigm and implied that the NOE, if it existed, could only represent the further oxygenation of the surface environment (Holland, 2009) and/or the oxygenation of the deep ocean (Canfield, 1998). A crucial prediction of the Nursall hypothesis was that the first metazoan fossils should be found above geochemical evidence for a rise in atmospheric oxygen, but it has taken a long time to approach consensus as to the timing of either.

The oldest undisputed traces of modern animal groupstrace fossils, sponge remains, and calcified tubes (of stemgroup cnidarians; see Xiao et al., 2000)_are at ca. $555 \mathrm{Ma}$, 20 million years older than the oldest animal fossils (trilobites) known to Darwin. The earliest multicellular macrofossils may be those from Newfoundland and England (e.g., Ivesheadia) and are at least as old as $575 \mathrm{Ma}$. Although their biological affinity is open to dispute, this problem need not be a cause of concern if macroscopic size itself can be shown to necessitate the presence of oxygen (Catling et al., 2005). Similarly, locomotion requires the energy provided by oxygen, and the first evidence for true mobility derives from the 


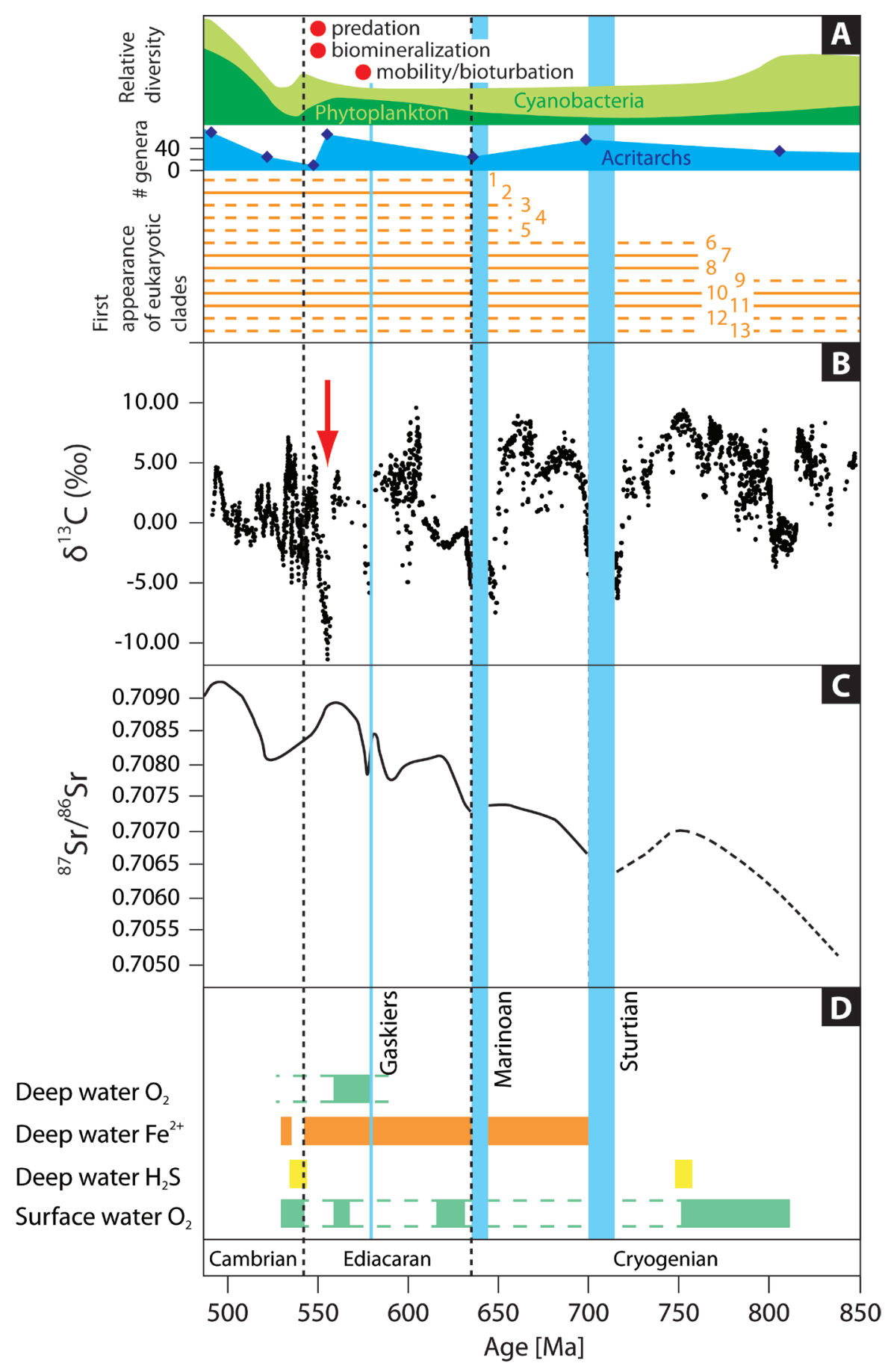

Figure 2. (A) Compilation showing the emergence of predation (Bengtson and Zhao, 1992), biomineralization (Grotzinger et al., 2000), and mobility (Liu et al., 2010); the relative diversity of cyanobacteria and phytoplankton through time (modified after Moczydlowska, 2008); acritarch diversity; and first appearance of eukaryotic clades. 1-brown algae; 2-animals; 3-haptophytes; 4-diatoms; 5-chrysophyte algae; 6-green algae; 7-lobose amoebae; 8-euglyphid amoebae; 9-fungi; 10-vaucheriacean algae; 11—red algae; 12-dinoflagellates; 13-ciliates (modified after Porter, 2004). (B) Secular variation in the carbon isotopic composition $\left(\delta^{13} \mathrm{C}\right)$ of marine carbonates from 850 to $490 \mathrm{Ma}$ (modified after Halverson et al., 2005; Halverson, 2006). The negative $\delta^{13} \mathrm{C}$ anomalies characterizing the Sturtian and Marinoan glacial intervals suggest they were globally synchronous. Shuram/Wonoka excursion indicated by red arrow. (C) Seawater ${ }^{87} \mathrm{Sr} /{ }^{86} \mathrm{Sr}$ curve for the same interval (data for the Ediacaran period from Sawaki et al., 2010). (D) Summary of marine conditions through the last half of the Neoproterozoic and into the early Cambrian (from Canfield et al., 2008). very same strata (Liu et al., 2010). If these latest findings are confirmed, Nursall's threshold must have been reached by ca. $570 \mathrm{Ma}$.

Microscopic metazoans may have existed even further back in time. Spiny acritarchs, similar to those that bear purported animal embryos, have been found in rocks as old as $635 \mathrm{Ma}$ (Yin et al., 2007; Cohen et al., 2009), while the earliest sponge biomarkers are of similar antiquity (Love et al., 2009). Although these findings imply that some "primitive," non-bilaterian animals existed during the Snowball Earth glaciations, in the absence of taxonomic identification, they fail to constrain ambient oxygen levels at that time.

The fossil record thus confirms that animals were relative latecomers, arriving more than a billion years after the evolution of the eukaryotic cell (Knoll et al., 2006). Molecular estimates for the origin of animals (Peterson et al., 2008) agree with the fossil record and converge on the Cryogenian period (850-635 Ma) and, in particular, its later, glacial parts (Snowball Earth) as the cradle of animal evolution. The same study constrains the emergence of bilaterian animals (and of locomotive and digestive musculature) to lie within the later Ediacaran period (after the ca. 580 Ma Gaskiers glaciation and the most extreme negative $\delta^{13} \mathrm{C}$ excursion of the entire rock record). While geological changes are regarded by some as "scenery rather than as major players" in early animal evolution (Budd, 2008), it is hard to ignore the extraordinary climatic and tectonic context. It has been suggested that evolutionary progress requires not only genetic possibility but also ecological opportunity (Knoll et al., 2006). Oxygenation, related to the remarkable tectonic and environmental revolutions of the later Neoproterozoic, may have provided such opportunity, but until recently we have known little about its nature and timing.

\section{MARSHALLING THE GEOCHEMICAL EVIDENCE FOR NEOPROTEROZOIC OXYGENATION}

\section{Carbon Isotopes}

The carbon isotope record provides insight into the Neoproterozoic global carbon cycle. Since the pioneering study of Knoll et al. (1986), it has been known that Neoproterozoic seawater 
was characterized by unusually high $\delta^{13} \mathrm{C}$, averaging $+5 \%$ before the onset of glaciation (Figs. 1 and 2). Such high values indicate that the proportion of carbon buried as organic matter was elevated from ca. $850 \mathrm{Ma}$ until ca. $720 \mathrm{Ma}$, and this has been linked to a general diversification of eukaryotic plankton, which altered the dynamics of organic matter production and decomposition (Knoll, 2003). Enhanced organic burial on subsiding, passive margins of the rupturing supercontinent, possibly carried down with the first widespread marine carbonate snow (Riding, 2006), may also have been responsible. Because organic burial allows oxygen released from photosynthesis to collect in the atmosphere, sustained high $\delta^{13} \mathrm{C}$ implies a drawdown in atmospheric $\mathrm{CO}_{2}$ and a concomitant rise in net oxygen production, albeit well before the earliest known metazoan fossils.

This story still holds but has since gained a twist. The Neoproterozoic carbon isotope record is also characterized by negative $\delta^{13} \mathrm{C}$ excursions of uncertain duration that began after $811 \mathrm{Ma}$ (Macdonald et al., 2010) and ended near the Precambrian-Cambrian boundary. The low $\delta^{13} \mathrm{C}$ values are commonly associated with episodes of cooling, while in some cases values are so low that they defeat explanation by conventional isotope mass balance. The largest of these, the Shuram-Wonoka excursion, took place during the middle of the Ediacaran period and was first identified by Pell et al. (1993) and Burns and Matter (1993) from strata in Australia and Oman, respectively. The excursion, constrained to beneath the first appearance of Cloudina and the disappearance of the large spiny, "acanthomorphic" acritarchs (typical of the early Ediacaran), is a global $\delta^{13} \mathrm{C}$ signal and can be explained by the oxidation of a vast deep-ocean pool of dissolved organic carbon (Rothman et al., 2003). This hypothesis is supported by the apparent decoupling of $\delta^{13} \mathrm{C}_{\text {carb }}$ and $\delta^{13} \mathrm{C}_{\text {org }}$ records (SwansonHysell et al., 2010), which, if confirmed, represents the massive consumption and injection of oxidants into the deep marine environment (Hayes and Waldbauer, 2006).

\section{Strontium Isotopes}

Estimating changes in net oxygen rise from the $\delta^{13} \mathrm{C}$ record requires the assumption that the rates of chemical weathering (and presumably also of carbon dioxide outgassing) remained constant or increased during the interval of high $\delta^{13} \mathrm{C}$. The ${ }^{87} \mathrm{Sr} /{ }^{86} \mathrm{Sr}$ ratio of seawater is predicted to rise if the relative contribution of continental weathering to the oceans increases and so can be used to test the nutrient (P) surge hypothesis. A marked rise during the Neoproterozoic was noted by Derry et al. (1992), and it reached an all-time maximum by the end of the Cambrian period (Shields, 2007). Superimposed on this rise are short-lived positive shifts caused by enhanced weathering after deglaciation, driven largely by warmer temperatures and unusually high atmospheric $\mathrm{pCO}_{2}$ (Kasemann et al., 2005; Bao et al., 2008). Pulses of globally integrated weathering rates raised net oxygen production, but increases in outgassing would be needed to sustain irreversible shifts in oxygen production (Shields, 2007). For example, the appearance of modern soil biota (e.g., Yuan et al., 2005) has been linked to irreversible changes in chemical weathering during the Neoproterozoic (Heckman et al., 2001; Lenton and Watson, 2004; Kennedy et al., 2006). However, any irreversible change in weathering rates will lead to global cooling unless compensated for by higher outgassing and an accelerated global carbon cycle, which may explain why Gondwanan orogenesis, characterized presumably by exceedingly high erosion rates, enhanced marine productivity and carbon dioxide drawdown (Campbell and Squire, 2010) and was accompanied by low $\delta^{13} \mathrm{C}$ values, high atmospheric $p \mathrm{CO}_{2}$, and some of the highest mean temperatures of the Phanerozoic (Trotter et al., 2008).

\section{Sulfur Isotopes}

Sulfur isotope discrimination (marine sulfate $\delta^{34} S$ - pyrite sulfide $\delta^{34} S$ ) increased to modern values during the Neoproterozoic-Cambrian transition (Canfield and Teske, 1996). Canfield and Teske argued that this change reflected a rise in atmospheric oxygen above the 0.05 present atmospheric level (PAL) necessary for sulfide-oxidizing bacteria (Beggiatoa). Recent studies indicate that this rise probably occurred during the middle Ediacaran (Fike et al., 2006; Halverson and Hurtgen, 2007), but sulfide oxidizers are now thought to have evolved much earlier (Johnston et al., 2005). It is difficult to know whether this increase in $\Delta^{34} \mathrm{~S}$ is related directly to higher oxygen levels or instead to the increased complexity of the sedimentary sulfur cycle caused by bioturbating animals (Canfield and Farquhar, 2009). In any case, this represents a change in the sedimentary sulfur cycle, possibly corresponding to an increase in the global ocean sulphate reservoir.

\section{Iron Speciation}

Canfield et al. (2007) presented evidence from a deep marine succession in Newfoundland that the proportion of highly reactive Fe versus total iron decreased to modern, oxic values after the ca. 580 Ma Gaskiers glaciation. Comparison with modern marine Fe speciation indicates that bottom waters changed locally from anoxic to oxic just before frondose life forms colonized the deep ocean seafloor in Newfoundland. Ediacaran macrofauna tolerated, and possibly required, free oxygen, consistent with their large size. Compilations of Fe speciation data (Canfield et al., 2008) indicate that the deep marine environment was anoxic during most of the Neoproterozoic, becoming ferruginous between about $720 \mathrm{Ma}$ and $580 \mathrm{Ma}$, but was occasionally sulfidic both before and after (Fig. 2). A major handicap arises from problems in correlating the Gaskiers and other mid-Ediacaran glacigenic deposits to published carbon and sulfur isotope records, and, more fundamentally, determining to which extent, if any, deep-water redox conditions influenced life and death in the productive upper layers of the water column (Butterfield, 2009).

\section{Redox-Sensitive Trace Metals}

Molybdenum concentrations (and Mo/total organic carbon [TOC] in euxinic shales) increase to Phanerozoic values in black shales sometime between $665 \mathrm{Ma}$ and $530 \mathrm{Ma}$ (Scott et al., 2008), a pattern also recognized in vanadium concentrations, which are generally enriched under similar conditions (Fig. 1). Because molybdenum is scavenged from seawater under sulfidic conditions, this shift could indicate that the global ocean molybdate reservoir rose during this time due to increased Mo delivery to the ocean through oxidative weathering and a retreat of sulfidic sinks. This supports the case that much of the Neoproterozoic deep ocean was anoxic until the late 
Precambrian (Canfield, 1998). Once the deep ocean had undergone its irreversible oxygenation (except for episodic oceanic anoxic events), the build-up of sulfate levels ensured that the effects of future carbon cycle perturbations on atmospheric oxygen could be buffered by an ocean sulfate capacitor.

\section{Chromium Isotopes}

This new method may be the only one capable of tracing increases in atmospheric oxygen, because chromium isotopes are fractionated during subaerial weathering. Sparse data imply that atmospheric oxygen levels were higher during the late Ediacaran than after the Great Oxygenation Event (Frei et al., 2009), but more data are needed.

In summary, the carbon and strontium isotope records provide evidence for increased carbon burial, which led to cooling and then to anoxic ferruginous conditions after ca. $750 \mathrm{Ma}$. The sulfur isotope record provides ambiguous evidence for atmospheric oxygenation during the later Neoproterozoic, but taken together, $\delta^{34} \mathrm{~S}$, Fe speciation, and Mo records indicate that a larger ocean sulphate reservoir led first to anoxic sulfidic conditions and later to the near-permanent ventilation of the deep marine environment. The extreme nature of the Neoproterozoic $\delta^{13} \mathrm{C}$ record still puzzles but also intriguingly suggests that the diversification of large, mobile, and skeletal metazoans around the Ediacaran-Cambrian boundary may have been contemporaneous with the further oxygenation of the surface environment.

\section{OXYGENATION AND THE FOSSIL RECORD}

It has been questioned whether deep ocean changes reflect a concomitant rise in atmospheric oxygen or merely indicate deep ocean ventilation due to the introduction of filter feeding and planktic metazoans (Butterfield, 2009); however, a general oxygenation event seems likely considering mounting evidence for elevated weathering rates, nutrient availability, and oxygen production during the Ediacaran. In this regard, we find the interpretation of large spiny acritarchs of the early Ediacaran as the diapause egg cysts of primitive metazoans (Yin et al., 2007) to be compelling. This interpretation permits the possibility that the metazoans evolved in response to environmental oxygen stress, while at the same time explaining why such characteristic acritarchs are never found in rocks younger than the postulated NOE (Cohen et al., 2009).

Although the Ediacaran $\delta^{13} \mathrm{C}$ record cannot be read simply in terms of organic carbon burial, the possibility of a vast pool of dissolved organic carbon is intriguing. If the Shuram-Wonoka $\delta^{13} \mathrm{C}$ anomaly represents the exhaustion of this pool, its culmination, at ca. $551 \mathrm{Ma}$ (Condon et al., 2005), could correspond to a rise in atmospheric oxygen just before the late EdiacaranCambrian emergence of modern animal phyla. Although the Cambrian explosion was undoubtedly accelerated through a cascade of knock-on effects arising from the arms race of frenetically evolving hard parts and eyes, etc., it seems likely that oxygenation, perhaps through the extra possibilities gained from their larger size and energy-sapping musculature, was a key factor. Furthermore, rising oxygen levels in the atmosphere and oceans could also have had an indirect effect on biological innovation by increasing the availability of bioessential trace elements (Anbar and Knoll, 2002).
But what about the earliest stages of metazoan evolution, which molecular clocks and the fossil record constrain to the earlier, but more enigmatic, interval of prolonged global cold? Did oxygen play a role in those, too? Evidence for an increase in fractional organic carbon burial, and therefore pre-glacial oxygenation, is strong. However, oxygen is more soluble in cold waters, and so the return of Archean-like ferruginous conditions by $750 \mathrm{Ma}$ seems counterintuitive and suggests that any rise in oxygen levels was reversible. In this regard, preEdiacaran pulses in oxygen production may have been curbed by the drawdown of $\mathrm{CO}_{2}$ and global cooling, which subdued rates of weathering and may have driven new innovations in photosynthesis (Riding, 2006). Whatever the reasons, animal diversification during this most eventful of geological intervals means that a new paradigm is emerging whereby the spread of anoxia rather than an abundance of oxygen could become the hallmark of early animal evolution.

Can we surmise from this unexpected association that our earliest metazoan ancestors were not oxygenophiles at all? To support this case, we note that many extant animals are facultative anaerobes and so are not wholly dependent on oxygen to make a living (Budd, 2008). As well as parasite worms, many free-living invertebrates and even the common mussel can live without oxygen. Astoundingly, some Loriciferans can even withstand free sulfide (Danovaro et al., 2010), which is toxic to all other known metazoans. This extraordinary ability is not secondarily derived but stems from their unusual mitochondria, which resemble hydrogenosomes. Until now, such organelles had only been found in single-celled life forms such as ciliates (Mentel and Martin, 2010) and so supports the argument that the ability to withstand anoxia and even sulphide may have existed near the base of the metazoan family tree (Theissen et al., 2003). The enzymes used in the facultatively anaerobic mitochondria of metazoans are nearly identical across all animal lineages (Martin and Müller, 2007), which indicates a common origin from a metazoan ancestor that lived in the variously oxic, ferruginous, and sulfidic Neoproterozoic oceans.

Being able to withstand anoxia, while at the same time benefitting from the energy yield of an aerobic metabolism, might also have been important during the earlier diversification of eukaryotes because all six eukaryote supergroups (Hampl et al., 2009) contain members with anaerobic mitochondria, including the green algae (Mus et al., 2007). The ability to inhabit oxygenated as well as anoxic environments is, therefore, hardwired into all major eukaryote lineages (Fritz-Laylin et al., 2010). Extending this to metazoans complements, if not challenges, the widespread presumption that oxygenation led directly to animal evolution and implies a three-stage process whereby metabolically versatile, multicellular heterotrophs initially evolved during a prolonged interval of climatic and environmental extremes as part of an overall diversification of eukaryotes on Earth. Mobility and macroscopic size were attained in a second stage during ocean ventilation in the Ediacaran period. Irreversible atmospheric oxygenation by the close of the Precambrian paved the way to the Cambrian explosion, leading to the emergence of all modern animal phyla. 


\section{ACKNOWLEDGMENTS}

Thanks to Nicholas Butterfield and Ian Campbell for their thoughtful and constructive reviews.

\section{REFERENCES CITED}

Anbar, A.D., and Knoll, A.H., 2002, Proterozoic ocean chemistry and evolution: A bioinorganic bridge?: Science, v. 297, no. 5584, p. 1137-1142.

Bao, H., Lyons, J.R., and Zhou, C., 2008, Triple oxygen isotope evidence for elevated $\mathrm{CO}_{2}$ levels after a Neoproterozoic glaciation: Nature, v. 453, no. 7194, p. 504-506.

Bengtson, S., and Zhao, Y., 1992, Predatorial borings in late Precambrian mineralized exoskeletons: Science, v. 257, no. 5068, p. 367-369.

Berkner, L.V., and Marshall, L.C., 1965, On the origin and rise of oxygen concentration in the Earth's atmosphere: Journal of the Atmospheric Sciences, v. 22, no. 3, p. 225-261.

Berner, R.A., Beerling, D.J., Dudley, R., Robinson, J.M., and Wildman, R.A., 2003, Phanerozoic atmospheric oxygen: Annual Review of Earth and Planetary Sciences, v. 31, no. 1, p. 105-134.

Budd, G.E., 2008, The earliest fossil record of the animals and its significance: Philosophical Transactions of the Royal Society B: Biological Sciences, v. 363, p. 1425-1434.

Burns, S.J., and Matter, A., 1993, Carbon isotopic record of the latest Proterozoic from Oman: Eclogae Geologicae Helvetiae, v. 86, no. 2, p. 595-607.

Butterfield, N.J., 2009, Oxygen, animals and oceanic ventilation: An alternative view: Geobiology, v. 7, no. 1, p. 1-7.

Campbell, I.H., and Allen, C.M., 2008, Formation of supercontinents linked to increases in atmospheric oxygen: Nature Geoscience, v. 1 , no. 8 , p. 554-558.

Campbell, I.H., and Squire, R.J., 2010, The mountains that triggered the Late Neoproterozoic increase in oxygen: The Second Great Oxidation Event: Geochimica et Cosmochimica Acta, v. 74, no. 15, p. 4187-4206.

Canfield, D.E., 1998, A new model for Proterozoic ocean chemistry: Nature, v. 396, no. 6710, p. 450-453.

Canfield, D.E., 2005, The early history of atmospheric oxygen: Homage to Robert M. Garrels: Annual Review of Earth and Planetary Sciences, v. 33, no. 1, p. 1-36.

Canfield, D.E., and Farquhar, J., 2009, Animal evolution, bioturbation, and the sulfate concentration of the oceans: Proceedings of the National Academy of Sciences, v. 106, no. 20, p. 8123-8127.

Canfield, D.E., and Teske, A., 1996, Late Proterozoic rise in atmospheric oxygen concentration inferred from phylogenetic and sulphurisotope studies: Nature, v. 382, no. 6587, p. 127-132.

Canfield, D.E., Poulton, S.W., and Narbonne, G.M., 2007, Late-Neoproterozoic deep-ocean oxygenation and the rise of animal life: Science, v. 315, no. 5808, p. 92-95.

Canfield, D.E., Poulton, S.W., Knoll, A.H., Narbonne, G.M., Ross, G., Goldberg, T., and Strauss, H., 2008, Ferruginous conditions dominated later Neoproterozoic deep-water chemistry: Science, v. 321, no. 5891, p. 949-952.

Catling, D.C., Glein, C.R., Zahnle, K.J., and McKay, C.P., 2005, Why $\mathrm{O}_{2}$ is required by complex life on habitable planets and the concept of planetary "oxygenation time": Astrobiology, v. 5, no. 3, p. 415-438.

Cohen, P.A., Knoll, A.H., and Kodner, R.B., 2009, Large spinose microfossils in Ediacaran rocks as resting stages of early animal: Proceedings of the National Academy of Science, v. 106, p. 6519-6524.

Condon, D., Zhu, M., Bowring, S., Wang, W., Yang, A., and Jin, Y., 2005, $\mathrm{U}-\mathrm{Pb}$ Ages from the Neoproterozoic Doushantuo Formation, China: Science, v. 308, no. 5718, p. 95-98.

Daly, R.A., 1907, The limeless ocean of pre-Cambrian time: American Journal of Science, v. s4-23, no. 134, p. 93-115.

Danovaro, R., Dell'Anno, A., Pusceddu, A., Gambi, C., Heiner, I., and Kristensen, R.M., 2010, The first metazoa living in permanently anoxic conditions: BMC Biology, v. 8, no. 1, p. 30.
Darwin, C.R., 1859, On the Origin of the Species: London, Murray, 502 p. Derry, L.A., Kaufman, A.J., and Jacobsen, S.B., 1992, Sedimentary cycling and environmental-change in the late Proterozoic-Evidence from stable and radiogenic isotopes: Geochimica et Cosmochimica Acta, v. 56, no. 3, p. 1317-1329.

Evans, D.A.D., 2009, The palaeomagnetically viable, long-lived and allinclusive Rodinia supercontinent reconstruction: Geological Society [London] Special Publication 327, p. 371-404.

Fairchild, I.J., and Kennedy, M.J., 2007, Neoproterozoic glaciation in the Earth System: Journal of the Geological Society, v. 164, no. 5, p. 895-921.

Fike, D.A., Grotzinger, J.P., Pratt, L.M., and Summons, R.E., 2006, Oxidation of the Ediacaran ocean: Nature, v. 444, no. 7120, p. 4.

Frei, R., Gaucher, C., Poulton, S.W., and Canfield, D.E., 2009, Fluctuations in Precambrian atmospheric oxygenation recorded by chromium isotopes: Nature, v. 461, no. 7261, p. 250-253.

Fritz-Laylin, L.K., Assaf, Z.J., Chen, S., and Cande, W.Z., 2010, Naegleria gruberi De Novo basal body assembly occurs via stepwise incorporation of conserved proteins: Eukaryotic Cell, v. 9, no. 6, p. 860-865, doi: 10.1128/EC.00381-09.

Grotzinger, J.P., Watters, W.A., and Knoll, A.H., 2000, Calcified metazoans in thrombolite-stromatolite reefs of the terminal Proterozoic Nama Group, Namibia: Paleobiology, v. 26, no. 3, p. 334-359.

Haldane, J.B.S., 1929, The origin of life: Rationalist Annual, v. 148, p. $3-10$.

Halverson, G.P, 2006, A Neoproterozoic chronology: Neoproterozoic Geobiology and Paleobiology, p. 231-271.

Halverson, G.P., and Hurtgen, M.T., 2007, Ediacaran growth of the marine sulfate reservoir: Earth and Planetary Science Letters, v. 263, no. 1-2, p. 32-44.

Halverson, G.P., Hoffman, P.F., Schrag, D.P., Maloof, A.C., and Rice, A.H.N., 2005, Toward a Neoproterozoic composite carbon-isotope record: Geological Society of America Bulletin, v. 117, no. 9, p. 1181-1207.

Hampl, V., Hug, L., Leigh, J.W., Dacks, J.B., Lang, B.F., Simpson, A.G.B., and Roger, A.J., 2009, Phylogenomic analyses support the monophyly of Excavata and resolve relationships among eukaryotic supergroups: Proceedings of the National Academy of Science, v. 106, p. 3859-3864.

Hayes, J.M., and Waldbauer, J.R., 2006, The carbon cycle and associated redox processes through time: Philosophical Transactions of the Royal Society B: Biological Sciences, v. 361, 1470, p. 931-950.

Heckman, D.S., Geiser, D.M., Eidell, B.R., Stauffer, R.L., Kardos, N.L., and Hedges, S.B., 2001, Molecular evidence for the early colonization of land by fungi and plants: Science, v. 293, no. 5532, p. 1129-1133.

Hofmann, H.J., Narbonne, G.M., and Aitken, J.D., 1990, Ediacaran remains from intertillite beds in northwestern Canada: Geology, v. 18, no. 12 , p. 1199-1202.

Hoffman, P.F., and Li, Z.-X., 2009, A palaeogeographic context for Neoproterozoic glaciation: Palaeogeography, Palaeoclimatology, Palaeoecology, v. 277, no. 3-4, p. 158-172.

Hoffman, P.F., Kaufman, A.J., Halverson, G.P., and Schrag, D.P., 1998, A Neoproterozoic Snowball Earth: Science, v. 281, no. 5381, p. 1342-1346.

Holland, H.D., 2002, Volcanic gases, black smokers, and the great oxidation event: Geochimica et Cosmochimica Acta, v. 66, no. 21, p. 3811-3826.

Holland, H.D., 2009, Why the atmosphere became oxygenated: A proposal: Geochimica et Cosmochimica Acta, v. 73, no. 18, p. 5241-5255.

Johnston, D.T., Wing, B.A., Farquhar, J., Kaufman, A.J., Strauss, H., Lyons, T.W., Kah, L.C., and Canfield, D.E., 2005, Active microbial sulfur disproportionation in the Mesoproterozoic: Science, v. 310, no. 5753, p. 1477-1479.

Kasemann, S.A., Hawkesworth, C.J., Prave, A.R., Fallick, A.E., and Pearson, P.N., 2005, Boron and calcium isotope composition in Neoproterozoic carbonate rocks from Namibia: Evidence for extreme 
environmental change: Earth and Planetary Science Letters, v. 231, no. $1-2$, p. 73-86.

Kennedy, M., Droser, M., Mayer, L.M., Pevear, D., and Mrofka, D., 2006, Late Precambrian oxygenation; Inception of the clay mineral factory: Science, v. 311, no. 5766, p. 1446-1449.

Kirschvink, J., 1992, Late Proterozoic low-latitude global glaciation: The Snowball Earth, in Schopf, J.W., and Klein, C., eds., The Proterozoic Biosphere: Cambridge University Press, p. 51-52.

Knoll, A.H., 2003, Life on a Young Planet: The First Three Billion Years of Evolution on Earth: Princeton, New Jersey, Princeton University Press, 304 p.

Knoll, A.H., Hayes, J.M., Kaufman, A.J., Swett, K., and Lambert, I.B., 1986, Secular variation in carbon isotope ratios from Upper Proterozoic successions of Svalbard and East Greenland: Nature, v. 321 , no. 6073 , p. $832-838$.

Knoll, A.H., Javaux, E.J., Hewitt, D., and Cohen, P., 2006, Eukaryotic organisms in Proterozoic oceans: Philosophical Transactions of the Royal Society B: Biological Sciences, v. 361, no. 1470, p. 1023-1038.

Lenton, T.M., and Watson, A.J., 2004, Biotic enhancement of weathering, atmospheric oxygen and carbon dioxide in the Neoproterozoic: Geophysical Research Letters, v. 31.

Liu, A.G., Mcllroy, D., and Brasier, M.D., 2010, First evidence for locomotion in the Ediacara biota from the 565 Ma Mistaken Point Formation, Newfoundland: Geology, v. 38, no. 2, p. 123-126.

Love, G.D., Grosjean, E., Stalvies, C., Fike, D.A., Grotzinger, J.P., Bradley, A.S., Kelly, A.E., Bhatia, M., Meredith, W., Snape, C.E., Bowring, S.A., Condon, D.J., and Summons, R.E., 2009, Fossil steroids record the appearance of Demospongiae during the Cryogenian period: Nature, v. 457, no. 7230, p. 718-721.

Macdonald, F.A., Schmitz, M.D., Crowley, J.L., Roots, C.F., Jones, D.S., Maloof, A.C., Strauss, J.V., Cohen, P.A., Johnston, D.T., and Schrag, D.P., 2010, Calibrating the Cryogenian: Science, v. 327, no. 5970, p. 1241-1243.

Marshall, C.R., 2006, Explaining the Cambrian "Explosion" of animals: Annual Review of Earth and Planetary Sciences, v. 34, no. 1, p. 355-384.

Martin, W.F., and Müller, M., 2007, Origin of mitochondria and hydrogenosomes: Heidelberg, Germany, Springer, $306 \mathrm{p}$.

Melezhik, V.A., Fallick, A.E., Hanski, E.J., Kump, L.R., Lepland, A., Prave, A.R., and Strauss, H., 2005, Emergence of an aerobic biosphere during the Archean-Proterozoic transition: Challenges of future research: GSA Today, v. 15, no. 11, p. 4-11.

Mentel, M., and Martin, W., 2010, Anaerobic animals from an ancient, anoxic ecological niche: BMC Biology, v. 8, no. 1, p. 32.

Moczydlowska, M., 2008, The Ediacaran microbiota and the survival of Snowball Earth conditions: Precambrian Research, v. 167, no. 1-2, p. 1-15.

Mus, F., Dubini, A., Seibert, M., Posewitz, M.C., and Grossman, A.R., 2007, Anaerobic acclimation in Chlamydomonas reinhardtii: Journal of Biological Chemistry, v. 282, no. 35, p. 25,475-25,486.

Nagy, R.M., Porter, S.M., Dehler, C.M., and Shen, Y., 2009, Biotic turnover driven by eutrophication before the Sturtian low-latitude glaciation: Nature Geoscience, v. 2, no. 6, p. 415-418.

Narbonne, G.M., 2005, The Ediacara Biota: Neoproterozoic origin of animals and their ecosystems: Annual Review of Earth and Planetary Sciences, v. 33, no. 1, p. 421-442.

Nursall, J.R., 1959, Oxygen as a prerequisite to the origin of the Metazoa: Nature, v. 183 , no. 4669 , p. $1170-1172$.

Oparin, A., 1938, The Origin of Life: New York, Macmillan, 270 p.

Payne, J., Boyer, A., Brown, J., Finnegan, S., Kowalewski, M., Krause, R., Lyons, S., McClain, C., McShea, D., and Novack-Gottshall, P., 2009, Two-phase increase in the maximum size of life over 3.5 billion years reflects biological innovation and environmental opportunity: Proceedings of the National Academy of Sciences, v. 106, no. 1, p. 24.

Pell, S.D., McKirdy, D.M., Jansyn, J., and Jenkins, R.J.F., 1993, Ediacaran carbon isotope stratigraphy of South Australia-An initial study:
Transactions of the Royal Society of South Australia, v. 117, no. 4, p. 153-161.

Peterson, K.J., Cotton, J.A., Gehling, J.G., and Pisani, D., 2008, The Ediacaran emergence of bilaterians: Congruence between the genetic and the geological fossil records: Philosophical Transactions of the Royal Society B: Biological Sciences, v. 363, no. 1496, p. 1435.

Porter, S.M., 2004, The fossil record of early eukaryotic diversification: Paleontological Society Papers, v. 10, p. 35-50.

Riding, R., 2006, Cyanobacterial calcification, carbon dioxide concentrating mechanisms, and Proterozoic-Cambrian changes in atmospheric composition: Geobiology, v. 4, p. 299-316.

Rothman, D.H., Hayes, J.M., and Summons, R.E., 2003, Dynamics of the Neoproterozoic carbon cycle: Proceedings of the National Academy of Sciences, v. 100, no. 14, p. 8124-8129.

Runnegar, B., 1991, Precambrian oxygen levels estimated from the biochemistry and physiology of early eukaryotes: Global and Planetary Change, v. 5, no. 1-2, p. 97-111.

Sawaki, Y., Ohno, T., Tahata, M., Komiya, T., Hirata, T., and Maruyama, S., Windley, B.F., Han, J., Shu, D., and Li, Y., 2010, The Ediacaran radiogenic $\mathrm{Sr}$ isotope excursion in the Doushantuo Formation in the Three Gorges area, South China: Precambrian Research, v. 176, p. 46-64.

Scott, C., Lyons, T.W., Bekker, A., Shen, Y., Poulton, S.W., Chu, X., and Anbar, A.D., 2008, Tracing the stepwise oxygenation of the Proterozoic ocean: Nature, v. 452, no. 7186, p. 5.

Shields, G.A., 2007, A normalised seawater strontium isotope curve: Possible implications for Neoproterozoic-Cambrian weathering rates and the further oxygenation of the Earth: Earth, v. 2, no. 2, p. 35-42.

Swanson-Hysell, N.L., Rose, C.V., Calmet, C.C., Halverson, G.P., Hurtgen, M.T., and Maloof, A.C., 2010, Cryogenian glaciation and the onset of carbon-isotope decoupling: Science, v. 328, no. 5978, p. 608-611.

Theissen, U., Hofmeister, M., Grieshaber, M., and Martin, W., 2003, Single eubacterial origin of eukaryotic sulfide: Quinine oxidoreductase, a mitochondrial enzyme conserved from the early evolution of eukaryotes during anoxic and sulfidic times: Molecular Biology and Evolution, v. 20, p. 1564-1574.

Trotter, J.A., Williams, I.S., Barnes, C.R., Lecuyer, C., and Nicoll, R.S., 2008, Did cooling oceans trigger Ordovician biodiversification? Evidence from conodont thermometry: Science, v. 321, no. 5888, p. 550-554.

Xiao, S., Yuan, X., and Knoll, A.H., 2000, Eumetazoan fossils in terminal Proterozoic phosphorites?: Proceedings of the National Academy of Sciences, v. 97, no. 25, p. 13,684-13,689.

Yin, L., Zhu, M., Knoll, A.H., Yuan, X., Zhang, J., and Hu, J., 2007, Doushantuo embryos preserved inside diapause egg cysts: Nature, v. 446, no. 7136, p. 661-663.

Yuan, X., Xiao, S., and Taylor, T.N., 2005, Lichen-like symbiosis 600 million years ago: Science, v. 308, no. 5724, p. 1017-1020.

Manuscript received 5 May 2010; accepted 16 June 2010. (1)

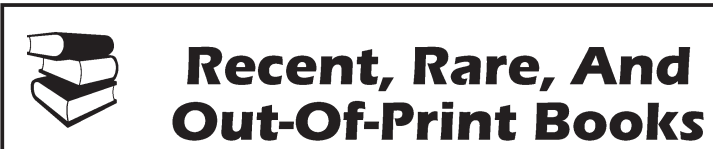

geoscience, paleontology, mineralogy, mining history, ore deposits, USGS and USBM publications, petroleum, Trails illustrated and National Forest Service Maps

$$
\text { http://booksgeology.com }
$$$$
\text { msbooks@booksgeology.com }
$$

WE PURCHASE BOOKS AND ENTIRE COLLECTIONS MS Book and Mineral Company

P.O. Box 6774, Lake Charles, LA 70606-6774 USA. 